\title{
A snapshot on composition and distribution of fish larvae across the North Atlantic Ocean
}

\author{
MOHD NASARUDIN HARITH ${ }^{1,3, \boldsymbol{v}}$, CIERAN O’ DONNELL ${ }^{2}$, GRAHAM JOHNSTON ${ }^{2}$, ANNE MARIE POWER \\ ${ }^{1}$ Faculty of Resource Science and Technology, Universiti Malaysia Sarawak. 94300 Kota Samarahan, Sarawak, Malaysia. Tel./fax.: +60-82-584521, \\ vemail: hmnasarudin@unimas.my \\ ${ }^{2}$ Fisheries Ecosystems Advisory Services, Marine Institute. Oranmore, Co. Galway, Ireland \\ ${ }^{3}$ Ryan Institute, School of Natural Sciences, National University of Ireland Galway. Galway, Ireland
}

Manuscript received: 20 September 2021. Revision accepted: 26 September 2021.

\begin{abstract}
Harith MN, O' Donnell C, Johnston G, Power AM. 2021. A snapshot on composition and distribution of fish larvae across the North Atlantic Ocean. Biodiversitas 22: 4496-4504. This study aims to describe the composition and distribution patterns of fish larvae communities across the North Atlantic Ocean. Several cruises were involved in the effort to collect the fish larvae samples. The sampling took place on the east side of the North Atlantic Ocean, towards the mid-Atlantic Ocean, and on the west side of the North Atlantic Ocean, near the eddies approaching Flemish Cap. A total of 9522 fish larvae were collected and identified from these surveys. These larvae came from 79 taxa and 29 families. Referring to the total abundance, considering all the sampled stations, Atlantic mackerel (Scomber scombrus) was the most abundant species (38.82\% of the total fish larvae abundance), followed by blue whiting (Micromesistius poutassou) (15.9\%). Referring to the Multi-dimensional scaling (MDS) ordination plots, two major stations clusters separate the on-shelf and off-shelf stations supported by SIMPER analysis. This study provides a snapshot of larval fish concentrations and assembly structure, but current knowledge suggests that the distribution of larval fish assemblages will be highly spatially variable, more research into plume front dynamics and their effects on the region's biota is needed to predict and understand changes.
\end{abstract}

Keywords: Assemblages, diversity, ichthyoplankton, larval, transatlantic

\section{INTRODUCTION}

Studying the species composition, abundance, and spatial and temporal distribution of fish larvae provides valuable data on the locations and seasons of spawning, particularly commercially important species. This knowledge allows researchers to understand the life cycle, behavior, and migration of fish, provides important scientific information to evaluate the reproduction success of different fish, and further state of recruitment and fish stocks that can be used for rational exploitation of fish resources. Early stages of fish development, especially larvae, are the most vulnerable to the changes in environmental conditions; therefore, the study of the state of fish larvae communities helps not only to estimate the reproduction success of fish populations and to predict future catches of commercially important species but also to monitor the anthropogenic impact and climate change in the marine ecosystem (Chesalina et al. 2013)

There are several studies documenting the fish larvae composition on the east side of the North Atlantic Ocean, and most of these studies are done separately in terms of sampling effort (Gowen et al. 1998; Duffy-Anderson et al. 2006; Ibaibarriaga et al. 2007; Giordano et al. 2015; McKinnon et al. 2015). As fish larvae are considered weak swimmers and categorized as part of the zooplankton group, one might say that there are very low or none of the fish larvae could be found, especially off the shelf and the middle of the North Atlantic Ocean. This statement stayed as claims as there was a lack of proper documentation in terms of publication on the composition of the fish larvae across the North Atlantic Ocean. Thus, the objective of this study is to describe the abundance and distribution patterns of fish larvae communities across the North Atlantic Ocean. The working hypothesis was that the composition pattern of fish larvae present differences between the areas studied according to the hydrographical factors/environmental analyzed. The information might be interesting as the oceanographic feature across the North Atlantic Ocean might influence the fish larvae composition.

\section{MATERIALS AND METHODS}

\section{Samples collection and study area}

The effort to collect the fish larvae across the North Atlantic Ocean was made through the participation of several cruises. The sampling was assigned as part of several cruises, namely CE14006: Transatlantic Cruise, CE15005: Blue Whiting Acoustic Survey (BWAS 2015), CE15007: Transatlantic Ocean Climate Survey 2015, CE16005: Blue Whiting Acoustic Survey (BWAS 2016), and CE16007: Transatlantic Survey 2016 (Figure 1). The location of the samplings included the side of the North Atlantic Ocean towards the mid-Atlantic Ocean and finished at the eddies area approaching Flemish Cap at the west side of the North Atlantic Ocean (Figure 1). The summary related to all sampling involved are shown in Table 1. 


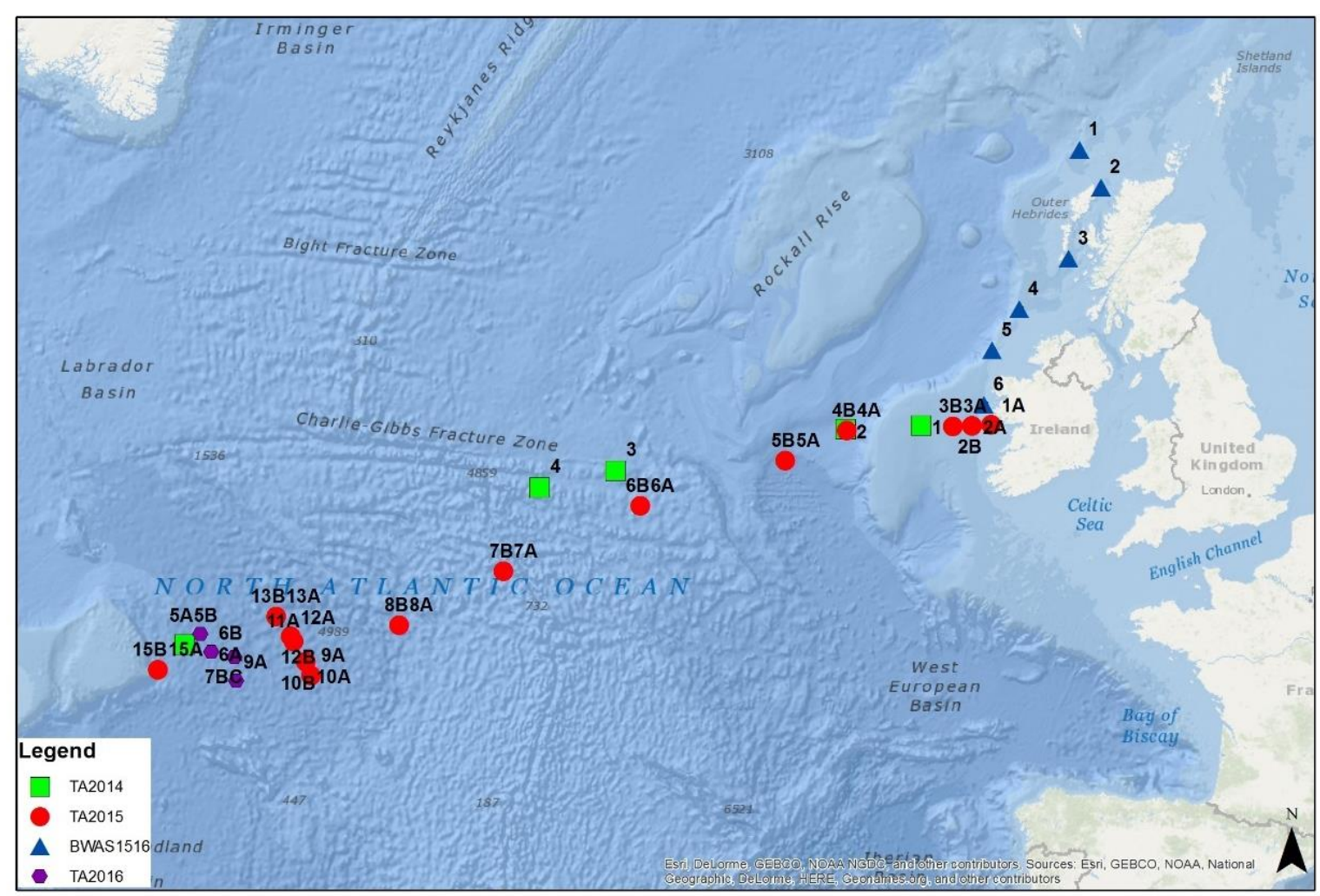

Figure 1. Fish larvae sampling stations across the North Atlantic Ocean. (Green squares: TA2014 - Stations from Transatlantic 2014, Red circles: TA2015 - Stations from Transatlantic 2015, Blue triangles: BWAS1516 - Stations from Blue whiting survey 2015 and 2016) and purple polygon: TA2016 - Transatlantic 2016

Table 1. Cruises and number of samples collected in this study

\begin{tabular}{lclc}
\hline \multicolumn{1}{c}{ Cruise } & $\begin{array}{c}\text { Date (Fish larvae } \\
\text { sampling) }\end{array}$ & $\begin{array}{c}\text { Location (Number of } \\
\text { samples involved }\end{array}$ & $\begin{array}{c}\text { Total number } \\
\text { of samples }\end{array}$ \\
\hline CE14006: Transatlantic Cruise & $13-19$ April 2014 & 1 CS, 1 OCS, 2 MA, 1 E & 5 \\
Blue Whiting Acoustic Survey (BWAS 2015) & $8-10$ April 2015 & 6 CS & 6 \\
CE15007: Transatlantic Ocean Climate Survey 2015 & $20-30$ April 2015 & 6 CS, 4 OCS, 6 MA, 11 E & 27 \\
Blue Whiting Acoustic Survey (BWAS 2016) & $3-5$ April 2016 & 11 CS & 11 \\
CE16007: Transatlantic Survey 2016 & $14-18$ April 2016 & 7E & 7 \\
\hline
\end{tabular}

Note: CS: Continental Shelf, OCS: Off continental shelf, MA: Mid Atlantic, E: Eddies

A total of 56 samples, which were collected from onshelf and off-shelf, were sampled. Fish larvae samples were collected with a 200-micron mesh net of the $100 \mathrm{~cm}$ diameter Hydro-Bios Ring Trawl (CalCOFI) net. Vertical net hauls were conducted from $200 \mathrm{~m}$ (or depth available if less than $200 \mathrm{~m}$ ) to the surface. For every net tow, a flowmeter was attached to the net to measure the volume of water filtered.

When weather conditions allowed, the fish larvae were sorted from the zooplankton samples and preserved in $85 \%$ ethanol. Otherwise, they were preserved in $4 \%$ buffered formalin and seawater and sorted later in the laboratory. Four distinct areas were examined for the analyses, and stations were groups as follows: CS: Continental Shelf, OCS: Off Continental Shelf, MA: Mid-Atlantic Ocean, and E: Eddies. These groups were based on the geographical aspects for the ocean except for eddies (E), which was based on the characteristic for the oceanographic target by the transatlantic sampling cruises.

\section{Laboratory work}

In the laboratory, all fish larvae (excluding that sorted on-board) were sorted from other zooplankton and transferred into $85 \%$ ethanol. These larvae were identified to the lowest possible taxon through their morphological characteristics, namely vertebrae/myomere counts, pigmentation, shapes, supination, fin development patterns, fin placement, and eye shape guided with appropriate identification keys (Russel 1976; Fahay 1983; Oliver and Fortuno 1991; Re and Meneses 2009).

\section{Standardization of data}

There were variations between stations in-depth, a distance of tow, and volume of water filtered through the 
net in each haul. Therefore, it was necessary to standardize the data before analysis. The data standardization in terms of volume of water filtered and number of fish larvae collected in each sample was done according to Smith and Richardson (1977):

Volume filtered $\left(\mathrm{m}^{3}\right)=($ Flowmeter revs $*$ Nose cone aperture * Efficiency factor) / Flowmeter calibration

Where, Flowmeter revs $=$ Number of revolutions made by the flowmeter propeller during the tow; Nose Cone Aperture $=$ The area of the nose-cone aperture of the sampler in $\mathrm{m}^{2}\left(\pi \mathrm{r}^{2}\right)$; Efficiency factor = Proportion accepted by the sampler in free flow; Flowmetercalibration $=$ The number of flowmeter revolutions per meter towed, obtained from the flume or sea calibration in free flow.

Larvae $\mathrm{m}^{-2}=($ Larvae counted $*$ Depth $*$ Factor $) /$ Volume filtered

Where, Larvae counted = Number of larvae in the sample; Depth = the sampling depth, in metres; Factor = Raising factor from sub-sample to whole sample.

The relative frequency $(f)$ of each species in the sampling stations was estimated according to the formula described by Goettsch and Hernández (2006):

$f=\mathrm{ss} / \mathrm{ts}$

Where, ss $=$ number of stations/sites in which the species occurs; ts $=$ total number of stations/sites.

The species frequency of occurrence (in percentage) was estimated as the ratio between the samples in which a species was found and the total number of samples collected.

\section{Data analysis}

Statistical analyses were performed to determine fish larvae community composition and abundance, their spatial distribution and species contribution to station ordination for both years. Analyses were carried out using PRIMER 7 (V7.0.12). Larval fish abundance was square-root transformed before further analysis to down-weight the contribution of highly abundant taxa. Hierarchical clustering methods were also used to determine a cohesive group of stations that had similar taxonomic composition. A Similarity Profile (SIMPROF), which is a permutation test to cluster stations a priori into statistically significant groups, was calculated using ranked Bray-Curtis similarities (observed) and those ranks were compared with permutations of the family density data (expected). The $\pi$ statistic was used to determine the difference between the observed and expected profile and was calculated using the sum of absolute differences, which was repeated 999 times. SIMPROF is calculated for each branch of the cluster analysis to determine if the cluster is significantly different using the $\pi$ value; if the $\pi$ value is greater than the expected, then the grouping is considered significant ( $\mathrm{p}<$ 0.1) (Clarke and Gorley 2015).

Multi-dimensional scaling (MDS) was used to visualize the similarity matrix of species community composition at different stations in a 2-dimensional MDS plot. Cluster analysis was carried out to identify groups of stations that aggregated at the same level of similarity. The major similarity levels were later used to visualize these station groups in the MDS plot. The stress level of the MDS plots indicates how well the set of biological data fit into twodimensional space. Values close to 0.2 give a useful representation of their distribution, while values above 0.2 indicated that the ordination were close to being arbitrary (Clarke et al. 2014).

Analysis of Similarity (ANOSIM) was used to test for differences in species composition between station clusters generated by SIMPROF within and between years. ANOSIM generates a measure of the degree of separation of sites, $\mathrm{R}$, which is close to 0 when similarities between and within sites are, on average, the same. An R-value of 1 indicates that all replicates within sites are more similar to each other than any replicate from different sites. In addition, ANOSIM gives a P-value like an ANOVA, with values of $\mathrm{P}<0.05$ indicating significance (Anderson and Walsh 2013). If differences were found using ANOSIM, then Similarity Percentage Analysis (SIMPER) was used to identify which species accounted for observed differences in assemblages between clusters and between years. SIMPER generates a ranking of the percent contribution of the species that are most important to the significant differences between factors. These analyses used a matrix composed of the Bray-Curtis similarity coefficient generated transformed species abundance data (Clarke et al. 2014).

\section{RESULTS AND DISCUSSION}

\section{Fish larvae composition and density}

A total of 9522 larvae were sorted from the 56 samples taken in this study. If sampling years were considered, the highest number of fish larvae collected was in 2015 with the number of catch was 6867, followed by 2016 (2558) and the lowest in the year 2014 (125). However, these numbers were also affected by the sampling cruise involved. The number of fish larvae catches for every cruise project was also considered. Comparing Transatlantic Cruises projects (TA) $(2014,2015$, and 2016) and Blue Whiting Acoustic Survey (BWAS) (2015 and 2016) cruises projects, the number of fish larvae catches from BWAS cruises were higher (5573 fish larvae) than TA (3977) even though there were more stations/samples involve from TA cruises compared to BWAS. This suggested that fish larvae are frequently found on the continental shelf compared to the samples collected offshelf.

Overall, these fish larvae identified belonged to 79 taxa and 29 families (Table 2). Referring to the total abundance, considering all the sampled stations, Atlantic mackerel (Scomber scombrus) (Figure 2) was the most abundant 
species (38.82\% of the total fish larvae abundance) followed by blue whiting (Micromesistius poutassou) $(15.9 \%)$. Both species were found from CS areas. In terms of groups, Gadoids was the most representative group (12 taxa), followed by gobies, lanternfishes, and turbos (7 taxa per group).

In terms of yearly sampling, in the year 2014, the fish larvae community consisted of only 125 individuals. From all 5 stations, only two stations contained fish larvae, and both stations were located on the east side of the North Atlantic Ocean (CS and OCS) (Figure 3, line 2014). Station 1 , located on the CS, showed the highest catch (84 individuals). Blue whiting was the most abundant species (41.6\% of the total fish larvae abundance), which was found in Station 1 (CS), followed by electric lanternfish (Electrona risso) $(19.2 \%$ of the total fish larvae abundance), which was found in station 2 (OCS). Zero fish larvae were caught from the remaining three stations from MA and E (Figure 3).

The number of fish larvae caught in 2015 sampling was 6839 individuals. When the sampling cruises were considered, the number of fish larvae caught in the TA cruise was higher than the BWAS cruise. However, if the four predetermined areas were considered, the number of fish larvae in CS would still be higher than others (OCS, MA, E). Atlantic mackerel was the most abundant species (47.9\% of the total fish larvae abundance), followed by blue whiting (18.9\% of the total fish larvae abundance). Even though both of these two species were found on the CS, a higher number of Atlantic mackerel were caught during the TA cruise (3133 larvae) compared to the number of Atlantic mackerel caught during BWAS cruise (139 larvae). On the other hand, more blue whiting larvae were caught during the BWAS cruise (1278) compared to only 13 caught during the TA cruise. This agrees with most previous studies, which showed the shelf edge and offshore banks to the west of Ireland and Scotland are the important spawning ground for Atlantic mackerel (Jansen and Gislason 2013) and blue whiting (Bartsch and Coombs 1997; Kloppmann et al. 2001). The sampling time for BWAS also coincided with blue whiting spawning, which occurs between late February and early May in a progressive spawning pattern (Bartsch and Coombs 1997), while the TA cruise coincided with Atlantic mackerel spawning season, which started in February to March, and expands northwards through April, May and June and end of the southwest of Ireland in July (Dransfeld et al. 2014).

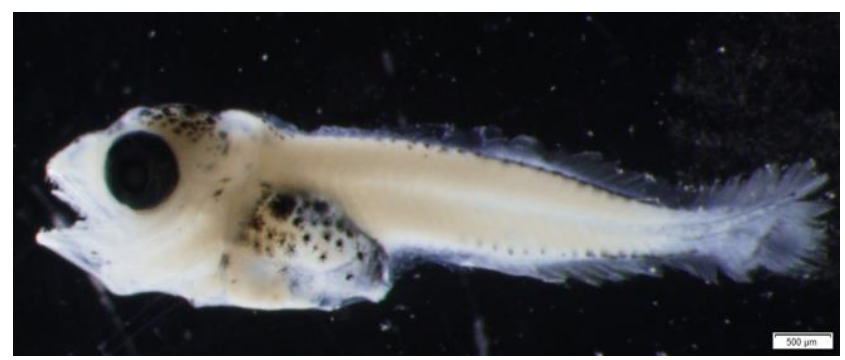

Figure 2. Scomber scombrus (Atlantic mackerel) larvae, the most abundant species identified

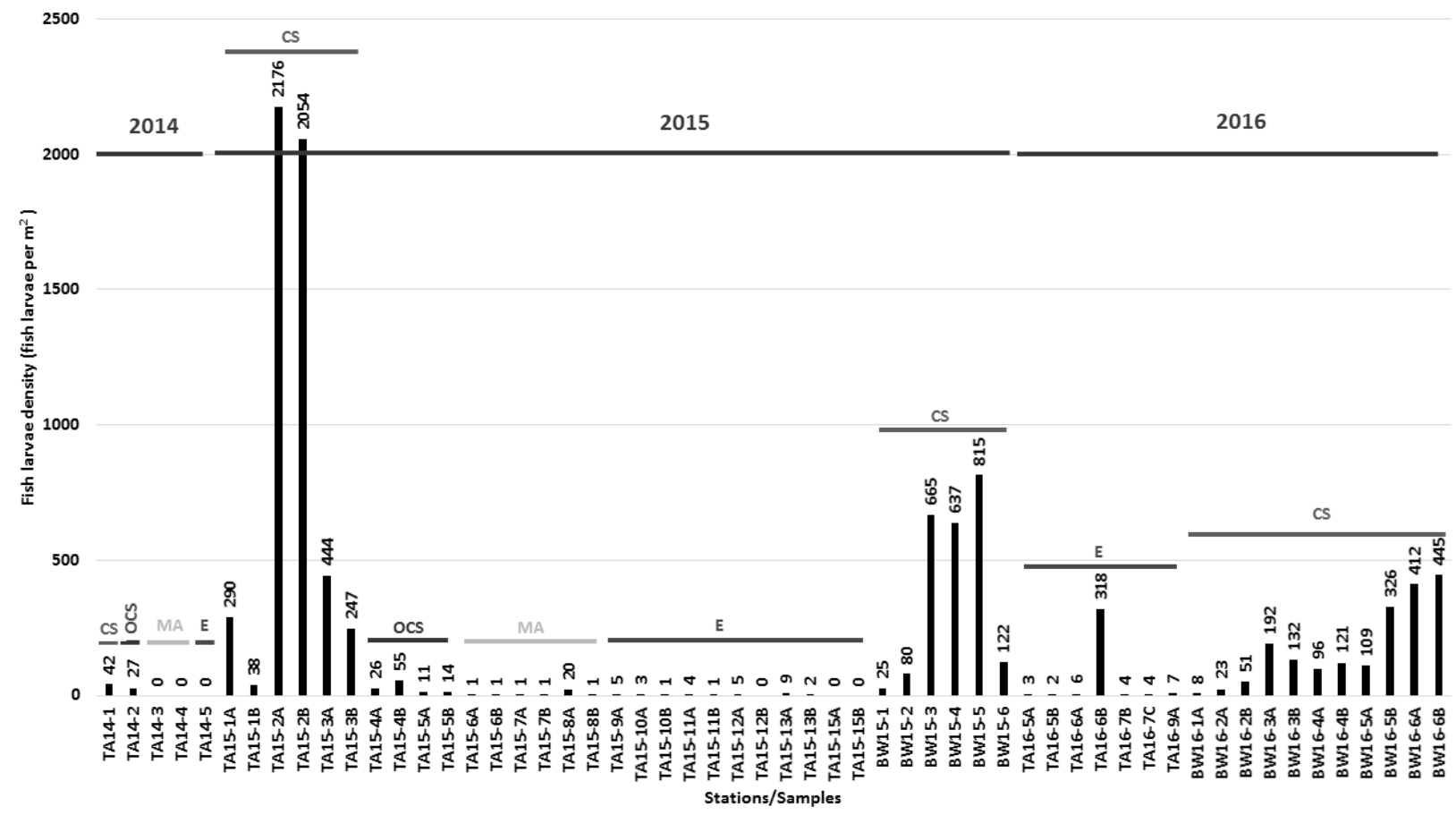

Figure 3. Fish larvae density for all stations from all sampling cruises. The red lines above indicate year of sampling (2014, 2015 and 2016) and lines on the top of the bars indicates the pre-determined areas namely CS: Continental Shelf, OCS: Off- Continental Shelf, MA: Mid-Atlantic and E: Eddies. The labelling on the station indicate the sampling program namely TA: Transatlantic cruises, BW: Blue Whiting Acoustic Survey 
In 2016, the total number of fish larvae caught was 2558. Comparing two sampling cruise programs, the planning was different in TA cruise where the sampling was focus only within eddies area (E) while BWAS cruise plan was still similar to the previous year (CS area). Only 58 fish larvae were caught from TA cruise, while the remaining 2500 fish larvae were caught from BWAS cruise. Based on the identified species, two same species, namely blue whiting and Atlantic mackerel, showed the highest abundance in 2016 (18.37\% and $16.58 \%$ of the total fish larvae abundance, respectively) of these species contributed from BWAS. None of them were found in the eddies (TA cruise).

Based on the number of fish larvae caught, more fish larvae were caught from CS areas than the other three predetermined areas (OCS, MA, and E). Even if the BWAS cruises were excluded (due to the cruise program aims, which were more specific in the blue whiting population survey, and TA cruises were not species-specific), the catch was still higher in CS compared to the other three predetermined areas.

The fish larval density across all areas across the North Atlantic Ocean for three years sampling is shown in Figure 3 . The density was highest in 2015, ranging from $1-2176$ fish larvae per $\mathrm{m}^{2}$, with a mean of 235 fish larvae per $\mathrm{m}^{2}$, followed by 2016, ranging from 3 - 445 fish larvae per $\mathrm{m}^{2}$, with a mean of 125 fish larvae per $\mathrm{m}^{2}$. The fish larvae density pattern can also be observed in Figure 3, wherein these three years, the fish larval density was higher in the continental area (CS) compared to the other area. This might be because the number of fish larvae caught was contributed mostly from BWAS sampling cruises, which were specifically focused on the blue whiting fish compared to the TA sampling, which was non-species specific. However, if only TA fish density were considered as TA sampling cruises were not species-specific, relatively, the pattern was also the same, which means that the population of fish larvae caught were higher in the CS areas compared to the other area.

Despite the pattern of the fish larvae assemblages which are higher in the CS area and lower at the OCS, MA and E. In 2016, the density of fish larvae in sample 6B at the eddies showed considerably higher (318 fish larvae per $\mathrm{m}^{2}$ ).

\section{Fish larvae spatial distribution}

Overall, based on the ANOSIM analysis, there were significant differences between CS, OCS, MA, and E areas in terms of fish larvae composition (global $\mathrm{R}=0.713$, $\mathrm{P}=0.001$ ). However, the ANOSIM Pairwise test showed no significant difference between $\mathrm{MA}$ and $\mathrm{E}$. In terms of yearly fish larvae composition, ANOSIM test showed no significant difference between all sampling years (2014, 2015, and 2016) (global $\mathrm{R}=0.033, \mathrm{P}=0.13$ ) as well as Pairwise tests among year groups.

MDS ordination shows those four-station clusters with a stress value of 0.13 (Figure 4.A). This stress value gives a useful 2-dimensional picture (Clarke et al. 2014). Referring to the MDS ordination plots, two major distinct stations clusters separate the on-shelf (CS) and off-shelf stations (OCS, MA, and E) (Figure 4.A and 4.B). This is supported by the SIMPER analysis, which showed relatively high dissimilarity between on-shelf and off-shelf areas (global R $=0.932, \mathrm{P}=0.01$ ). These results characterize two discrete significant larval fish assemblage groups, which probably reflect the water mass category present at stations (Paulic and Papst 2013).

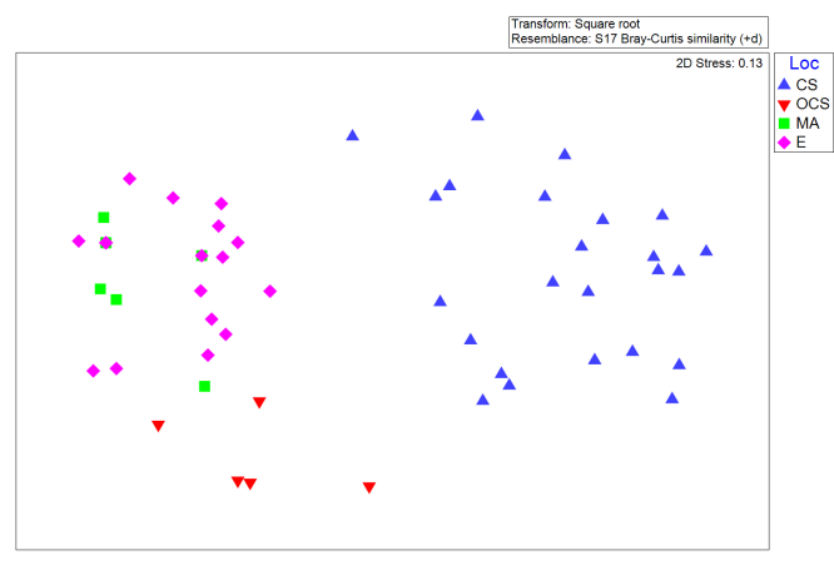

$\mathbf{A}$

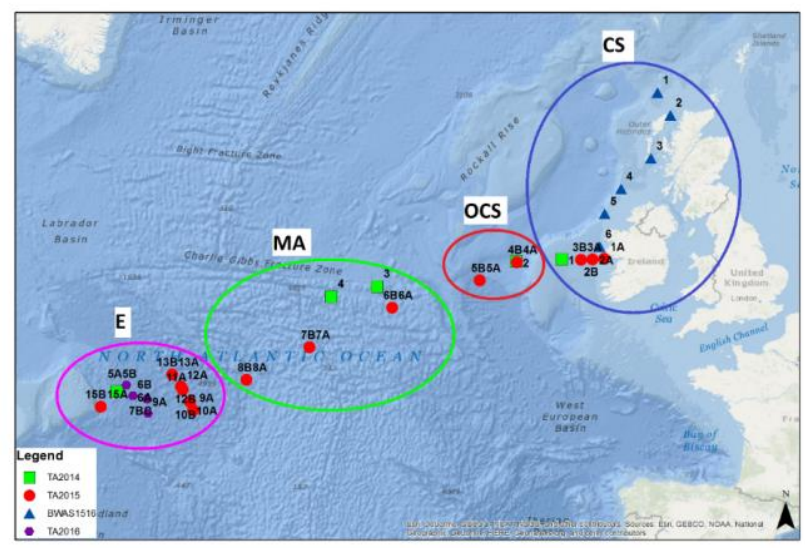

$\mathbf{B}$

Figure 4. A. Multi-dimentional scaling (MDS) ordination method representing fish larvae assemblages from four pre-defined areas, B. Stations with pre-defined locations (circles), CS: Continental Shelf, OCS: Off Continental Shelf, MA: Mid-Atlantic Ocean and E: Eddies 
Table 2. Species composition of fish larvae community from all 56 stations. Numbers of collected specimens, relative abundance on total catches and frequency index of positive hauls on the total samples $\left(\mathrm{f}_{\mathrm{i}}=\mathrm{n}_{1} / \mathrm{NT}\right)$

\begin{tabular}{|c|c|c|c|c|}
\hline Family & Taxa & $\mathbf{n}$ & Relatve abundance $(\%)$ & Relative frequency $(\%)$ \\
\hline \multirow[t]{3}{*}{ Ammodytidae } & Ammodytes marinus & 342 & 3.59 & 16.07 \\
\hline & Ammodytes tobianus & 6 & 0.06 & 1.79 \\
\hline & Gymnammodytes semisquamatus & 2 & 0.02 & 1.79 \\
\hline Argentinidae & Argentina sphyraena & 45 & 0.47 & 23.21 \\
\hline \multirow[t]{3}{*}{ Bathylagidae } & Bathylagus euryops & 2 & 0.02 & 3.57 \\
\hline & Bathylagus sp. & 2 & 0.02 & 3.57 \\
\hline & Dolicholagus longirostris & 1 & 0.01 & 1.79 \\
\hline Blenniidae & Lipophrys pholis & 2 & 0.02 & 1.79 \\
\hline \multirow[t]{4}{*}{ Callionymidae } & Callionymus maculatus & 3 & 0.03 & 1.79 \\
\hline & Callionymus lyra & 50 & 0.53 & 12.50 \\
\hline & Callionymus reticulatus & 98 & 1.03 & 23.21 \\
\hline & Callionymus sp. & 2 & 0.02 & 3.57 \\
\hline Caproidae & Capros aper & 24 & 0.25 & 8.93 \\
\hline Carapidae & Echiodon drummondii & 3 & 0.03 & 3.57 \\
\hline Chlorophthalmidae & Chlorophthalmus agassizi & 2 & 0.02 & 1.79 \\
\hline \multirow{2}{*}{ Clupeidae } & Clupea herengus & 11 & 0.12 & 3.57 \\
\hline & Sardina pilchardus & 44 & 0.46 & 12.50 \\
\hline \multirow[t]{13}{*}{ Gadidae } & Gadiculus argenteus & 120 & 1.26 & 16.07 \\
\hline & Gadus morhua & 26 & 0.27 & 14.29 \\
\hline & Melanogrammus aeglefinus & 205 & 2.15 & 25.00 \\
\hline & Merlangius merlangus & 185 & 1.94 & 19.64 \\
\hline & Micromesistius poutassou & 1817 & 19.08 & 35.71 \\
\hline & Pollachius pollachius & 39 & 0.41 & 19.64 \\
\hline & Pollachius virens & 9 & 0.09 & 5.36 \\
\hline & Pollachius sp. & 1 & 0.01 & 1.79 \\
\hline & Trisopterus esmarkii & 543 & 5.70 & 30.36 \\
\hline & Trisopteus minutus & 137 & 1.44 & 28.57 \\
\hline & Trispoterus luscus & 54 & 0.57 & 12.50 \\
\hline & Trisopterus sp. & 4 & 0.04 & 3.57 \\
\hline & Unidentified gadoid & 8 & 0.08 & 3.57 \\
\hline Gobiesocidae & Lepadogaster lepadogaster & 1 & 0.01 & 1.79 \\
\hline \multirow[t]{7}{*}{ Gobiidae } & Gobius cruentatus & 23 & 0.24 & 7.14 \\
\hline & Gobius niger & 42 & 0.44 & 8.93 \\
\hline & Gobius flavescens & 3 & 0.03 & 1.79 \\
\hline & Lebetus guilleti & 3 & 0.03 & 5.36 \\
\hline & Lebetus scorpioides & 7 & 0.07 & 5.36 \\
\hline & Pomatoschistus microps & 7 & 0.07 & 7.14 \\
\hline & Pomatoschistus minutus & 6 & 0.06 & 5.36 \\
\hline \multirow[t]{2}{*}{ Labridae } & Centrolabrus exoletus & 2 & 0.02 & 1.79 \\
\hline & Symphodus melops & 1 & 0.01 & 1.79 \\
\hline Lophiidae & Lophius piscatorius & 1 & 0.01 & 1.79 \\
\hline \multirow{4}{*}{ Lotidae } & Brosme brosme & 3 & 0.03 & 3.57 \\
\hline & Ciliata mustela & 320 & 3.36 & 26.79 \\
\hline & Molva molva & 5 & 0.05 & 1.79 \\
\hline & "Rockling" & 42 & 0.44 & 12.50 \\
\hline Merlucciidae & Merluccius merluccius & 66 & 0.69 & 17.86 \\
\hline \multirow[t]{7}{*}{ Myctophidae } & Electrona risso & 52 & 0.55 & 23.21 \\
\hline & Lampanyctus tenuiformis & 1 & 0.01 & 1.79 \\
\hline & Hygophum hygomii & 8 & 0.08 & 3.57 \\
\hline & Hygophum reinhardtii & 48 & 0.50 & 16.07 \\
\hline & Myctophum punctatum & 78 & 0.82 & 16.07 \\
\hline & Symbolophorus veranyi & 1 & 0.01 & 1.79 \\
\hline & Diaphus spp. & 1 & 0.01 & 1.79 \\
\hline Ophichthidae & Myrophis punctatus & 2 & 0.02 & 3.57 \\
\hline Ophidiidae & Unidentified Ophidiidae & 2 & 0.02 & 1.79 \\
\hline \multirow[t]{4}{*}{ Paralepididae } & Arctozenus risso & 2 & 0.02 & 3.57 \\
\hline & Magnisudis atlantica & 11 & 0.12 & 8.93 \\
\hline & Macroparalepis brevis & 1 & 0.01 & 1.79 \\
\hline & Paralepis coregonoides & 7 & 0.07 & 8.93 \\
\hline \multirow[t]{3}{*}{ Phosichthyidae } & Pollichthys mauli & 6 & 0.06 & 3.57 \\
\hline & Vinciguerria nimbaria & 1 & 0.01 & 1.79 \\
\hline & Vinciguerria sp. & 1 & 0.01 & 1.79 \\
\hline
\end{tabular}




\begin{tabular}{llccc}
\hline Pleuronectidae & Glyptocephalus cynoglossus & 103 & 1.08 & 21.43 \\
& Hippoglossoides platessoides & 29 & 0.30 & 7.14 \\
& Microstomus kitt & 152 & 1.60 & 19.64 \\
& Undientified pleuronectidae & 8 & 0.08 & 7.14 \\
Scombridae & Scomber scombrus & 3696 & 38.82 & 14.29 \\
Scophthalmidae & Lepidorhombus boscii & 2 & 0.02 & 1.79 \\
& Lepidorhombus whiffiagonis & 202 & 2.12 & 3.57 \\
& Phrynorhombus norvegicus & 2 & 0.02 & 1.79 \\
& Scophthalmus maximus & 1 & 0.01 & 1.79 \\
& Scophthalmus rhombus & 1 & 0.01 & 1.79 \\
Soleidae & Zeugopterus regius & 2 & 0.02 & 14.29 \\
& Zeugopterus punctatus & 32 & 0.34 & 3.57 \\
Buglossidium luteum & 5 & 0.05 & 19.64 \\
Stomiidae & Microchirus variegatus & 42 & 0.44 & 5.36 \\
Synodontidae & Pegusa lascaris & 5 & 0.05 & 7.14 \\
Trachinidae & Solea solea & 5 & 0.05 & 10.71 \\
Triglidae & Stomias boa ferox & 39 & 0.41 & 1.79 \\
Unidentified & Trachinocephalus myops & 1 & 0.01 & 1.79 \\
\hline
\end{tabular}

This situation was supported by SIMPER analysis which showed that the pre-defined groups of areas (CS, OCS, MA, and E) had different grades of between-stations similarity. The highest between-stations similarity was given for OCS stations with $27.97 \%$ similarity, followed by CS stations with an average $27.62 \%$ similarity. E stations showed $15.97 \%$ similarities, and the lowest similarity was showed by MA stations $(6.96 \%)$. The species contributed for area OCS between-stations similarities were boa dragonfish (Stomias boa ferox), electric lanternfish (Electrona risso), and blue-whiting (Micromesistius poutassou). While for CS stations, the species contributed were blue-whiting (Micromesistius poutassou), Atlantic mackerel (Scomber scombrus), five beard rockling (Ciliata mustela), Norway pout (Trisopterus esmarkii), megrim (Lepidorhombus whiffiagonis), haddock (Melanogrammus aeglefinus), poor cod (Trisopteus minutus) and whiting (Merlangius merlangus). On the mid-Atlantic stations (MA) and the eddies stations (E), the species contributed belongs to the lanternfish family, namely electric lanternfish (Electrona risso), spotted lanternfish (Myctophum punctatum), and Reinhardt's lantern fish (Hygophum reinhardtii).

If the dissimilarity between the pre-defined group is considered, the percentage average showed considerably high values. It started with CS and MA $(98.80 \%$ dissimilarity), followed by $\mathrm{CS}$ and $\mathrm{E}(97.10 \%$ dissimilarity), and the lowest showed by OCS and E (88.20\% dissimilarity). The species contributed for CS-MA dissimilarity were blue-whiting and Atlantic mackerel (10.34\% and $10.20 \%$ Contrib, respectively). These two species were also contributed to the CS-E dissimilarity relationship. For OCS-E dissimilarity, three species were contributed, namely boa dragonfish, electric lanternfish, and spotted lanternfish.

Based on these results, several potential aspects need to be considered. One is the difference between water masses in the region. Nearshore estuaries and river input have a significant effect on the waters of continental shelves in many parts of the world and are known for their high primary and secondary productivity and abundance of fish larvae (Beck et al. 2001). Changes in the larval fish assemblage composition are also observed along gradients of water depth from shallow coastal waters to the marine shelf. A variety of factors can influence patterns associated with the structure of the assembly. For example, Muhling et al. (2008) and Gray and Miskiewicz (2000) illustrate the impact of water mass structure and movement on assembly patterns and geographic location, while Doyle et al. (1993) and Harris et al. (2001) explore how variations in species life history and spawning patterns can affect those patterns. Local wind conditions, bathymetry, distance from shore (Duffy-Anderson et al. 2006), and the amount of discharged water and sea ice (Carmack and Macdonald 2002; Faria et al. 2006) are the results of related variability of water mass patterns and movement in the nearshore area. This can complicate the concept of assembly distributions and thus define assembly boundaries among various other factors (e.g. fronts, eddies, seasonal variance, and sampling time). The associations of larval assemblages with water masses in the Canadian Beaufort Sea nearshore are not inherently fixed in time or space; rather, they are versatile and change-sensitive (Duffy-Anderson et al. 2006).

Adult spawning strategies (demersal vs. pelagic) can also affect the distribution and assembly structure of larval fish (Doyle et al. 1993; Harris et al. 2001), resulting in a phenomenon called adaptive convergence (McGowen 1993; Duffy-Anderson et al. 2006). The composition of larval assemblages, the dominant species, in particular, reflects the different spawning strategies of adult fish. Adult Atlantic mackerel, for example, perform extensive annual migrations. The generic pattern is as follows: Atlantic mackerel gather in the northern North Sea at the end of autumn and form large dense schools, migrating towards the southwest along the shelf edge (Walsh et al. 1995; Reid et al. 1997). This migration from pre-spawning involves shorter or longer stops that are sometimes referred to as over-wintering periods. The schools disperse at the 
end of winter, and mackerel start spawning along the edge of the western European shelf, from Portugal to northwestern Scotland. Fish from both the southern spawning component (spawning along the Iberian Peninsula) and the component of the west (spawning from southwest France to Scotland) migrate to the same feeding grounds in the North Sea and Nordic Seas after spawning (Holst and Iversen 1999; Uriarte and Luciob 2001; Cotano and Álvarez 2003).

A member of the gadoid (cod) family, the blue whiting, is a common species in the northeast Atlantic. Along the continental borders to the west of the British Isles are the largest breeding grounds. The seasonal period, mostly from March to May with a peak in April, is very short. The geographical range of this species ranges from the Canary Islands to Spitzbergen $\left(26^{\circ} \mathrm{N}-82^{\circ} \mathrm{N}\right)$ along the continental shelf in the NE Atlantic, with smaller populations in the NW Atlantic and Mediterranean Sea (Heino and Godo 2002). At 2-7 years of age, adults reach maturation and undertake long yearly migrations from feeding grounds to spawning grounds and back again (Bailey and Heath 2001; Miesner and Payne 2018). Most NE Atlantic blue whiting aggregates spawn each year between March and April in the area around the Porcupine Bank, west of Ireland and Scotland (Monstad 1990; Hátún et al. 2009). Spawning takes place at depths of around $200-400 \mathrm{~m}$, and they are concentrated in the upper $60 \mathrm{~m}$ of the water column (Bartsch and Coombs 1997). In the Norwegian Sea, most larvae migrate north into feeding grounds (Monstad 1990) and in May and June spend fish returning north (Bailey and Heath 2001). Larvae migrate south to feeding areas in the Bay of Biscay in far smaller numbers (Carrera et al. 2001; Blanluet et al. 2019), a place called nursery land, fish from the region, and from resident populations to the west and southwest of Ireland, leading to the spawning aggregation of the Porcupine Bank (Miesner and Payne 2018). The extent of the spawning mix is uncertain, but morphometric and meristic data and parasite load data indicate that within the main spawning portion, there are two stocks, a northern stock spawning north of the Porcupine Bank and a southern stock spawning south of the Bank and along the continental slope (Heino and Godo 2002; Gonçalves et al. 2017).

In conclusion, 9522 fish larvae were collected and identified from this study which belongs to 79 taxa and 29 families. Considering all the sampled stations, Atlantic mackerel was the most abundant species $(38.82 \%$ of the total fish larvae abundance), followed by blue whiting $(15.9 \%)$. The density of fish larvae was higher on the shelf compared to the off-shelf stations. Based on the Multidimensional scaling (MDS) ordination plots, two major stations clusters separate the on-shelf and off-shelf stations supported by SIMPER analysis. This survey shed some information on the composition of the fish larvae and their distribution across the North Atlantic Ocean. However, further work needs to be done to obtain more information regarding the diversity and distribution of these larvae and their relationship intrinsically (inter-population relationship) or extrinsically (contribution of environmental forcing).

\section{ACKNOWLEDGEMENTS}

The authors are thankful to all the technicians and crew onboard, especially from Marine Institute Ireland, who aided in the sampling and collecting of samples. Thanks to Martin Ryan Institute, the National University of Ireland Galway for supporting transportation and lab facilities. The first author is the recipient of SLAI Scholarship from the Ministry of Higher Education (MoHE), Malaysia. Author's contribution: Mohd Nasarudin Harith, Graham Johnston, and Cieran O' Donnell were involved in field sampling. Mohd Nasarudin Harith conducted laboratory work, including larvae identification and data analysis. Mohd Nasarudin Harith and Anne Marie Power wrote the article.

\section{REFERENCES}

Anderson MJ, Walsh DCI. 2013. PERMANOVA, ANOSIM, and the Mantel test in the face of heterogeneous dispersions: What null hypothesis are you testing? Ecol Monogr 83: 557-574. DOI: $10.1890 / 12-2010.1$

Bailey MC, Heath 2001. Spatial variability in the growth rate of blue whiting (Micromesistius poutassou) larvae at the shelf edge west of the UK. Fish Res 50: 73-87. DOI: 10.1016/S0165-7836(00)00243-5

Bartsch J, Coombs S. 1997. A numerical model of the dispersion of blue whiting larvae, Micromesistius poutassou (Risso), in the eastern North Atlantic. Fish Oceanogr 6: 141-154. DOI: 10.1046/j.13652419.1997.00036.x

Beck MW, Heck KL, Able KW, Childers DL, Eggleston DB, Gillanders BM, Halpern B, Hays CG, Hoshino K, Minello TJ, Orth RJ, Sheridan PF, Weinstein MP. 2001. The identification, conservation, and management of estuarine and marine nurseries for fish and invertebrates. Biosci 51: 633-641. DOI: 10.1641/00063568(2001)051[0633:TICAMO]2.0.CO;2

Blanluet A, Doray M, Berger L, Romagnan J, Bouffant NL, Lehuta S, Petitgas P. 2019. Characterization of sound scattering layers in the Bay of Biscay using broadband acoustics, nets and video. PLoS One 14: 0223618. DOI: 10.1371/journal.pone.0223618

Carmack EC, Macdonald RW. 2002. Oceanography of the Canadian shelf of the Beaufort Sea: A setting for marine life. Arctic 55: 29-45. DOI: 10.14430/arctic733. DOI: 10.14430/arctic733

Carrera P, Meixide M, Porteiro C, Miquel J. 2001. Study of the blue whiting movements around the Bay of Biscay using acoustic methods. Fish Res 50: 151-161. DOI: 10.1016/S0165-7836(00)00248-4

Chesalina T, Al-Kharusi L, Al-Aisry A. 2013. Study of diversity and abundance of fish larvae in the South-western Part of the Sea of Oman in 2011-2012. J Biol Agric Healthc 3 (1): 30-43

Clarke K, Gorley R. 2015. PRIMER v7: User Manual/Tutorial. PRIMERE Ltd, United Kingdom.

Clarke KR, Gorley RN, Somerfield PJ, Warwick RM. 2014. Change in Marine Communities: An Approach to Statistical Analysis and Interpretation, 3rd edition. PRIMER-E Ltd, United Kingdom.

Cotano U, Álvarez P. 2003. Growth of young-of-the-year mackerel in the Bay of Biscay. J Fish Biol 62 (5): 1010-1020. DOI: 10.1046/j.10958649.2003.00093.x

Doyle MJ, Morse WW, Kendall AW. 1993. A Comparison of Larval Fish Assemblages in the Temperate Zone of the Northeast Pasific and Northwest Atlantic Oceans. Bull Mar Sci Miami 53 (2): 588-644.

Dransfeld L, Maxwell H, Moriarty M, Nolan C, Kelly E, Pedreschi D, Slattery N, Connolly P. 2014. North Western Waters Atlas 3rd Edition. Marine Institute, Ireland.

Duffy-Anderson JT, Busby MS, Mier KL, Deliyanides CM, Stabeno PJ. 2006. Spatial and temporal patterns in summer ichthyoplankton assemblages on the eastern Bering Sea shelf 1996-2000. Fish Oceanogr 15: 80-94. DOI: 10.1111/j.1365-2419.2005.00348.x

Fahay MP. 1983. Guide to the early stages of marine fishes occurring in the Western North Atlantic Ocean, Cape Hatteras to the Southern Scotian Shelf. J Northwest Atl Fish Sci 4: 3-423. DOI: 10.2960/J.v4.a1 
Faria A, Morais P, Chícharo MA. 2006. Ichthyoplankton dynamics in the Guadiana estuary and adjacent coastal area, South-East Portugal. Estuar Coast Shelf Sci 70: 85-97. DOI: 10.1016/j.ecss.2006.05.032

Giordano D, Profeta A, Busalacchi B, Minutoli R, Guglielmo L, Bergamasco A, Granata A. 2015. Summer larval fish assemblages in the Southern Tyrrhenian Sea (Western Mediterranean Sea). Mar Ecol 36: 12123. DOI: $10.1111 / \mathrm{maec} .12123$

Goettsch B, Hernández HM. 2006. Beta diversity and similarity among cactus assemblages in the Chihuahuan Desert. J Arid Environ 65: 513-528. DOI: 10.1016/j.jaridenv.2005.08.008

Gonçalves P, Ávila De Melo A, Murta AG, Cabral HN. 2017. Blue whiting (Micromesistius poutassou) sex ratio, size distribution and condition patterns off Portugal. Aquat Living Resour 30: 24. DOI: 10.1051/alr/2017019

Gowen RJ, Raine R, Dickey-Collas M, White M. 1998. Plankton distributions in relation to physical oceanographic features on the southern Malin Shelf, August 1996. ICES J Mar Sci 55: 1095-1111. DOI: $10.1006 /$ jmsc. 1998.0418

Gray CA, Miskiewicz AG. 2000. Larval fish assemblages in south-eas Australian coastal waters: Seasonal and spatial structure. Estuar Coast Shelf Sci 50: 549-570. DOI: 10.1006/ecss.1999.0595

Harris SA, Cyrus DP, Beckley LE. 2001. Horizontal trends in larval fish diversity and abundance along an ocean-estuarine gradient on the Northern KwaZulu-Natal Coast, South Africa. Estuar Coast Shelf Sci 53: 221-235. DOI: 10.1006

Hátún H, Payne MR, Jacobse JA. 2009. The north atlantic subpolar gyre regulates the spawning distribution of blue whiting (Micromesistius poutassou). Can J Fish Aquat Sci 66: 759-770. DOI: 10.1139/F09. 037

Heino M, Godo OR. 2002. Blue whiting - a key species in the mid-water ecosystems of the north-eastern Atlantic. ICES C 2002/L28 1-6

Holst JC, Iversen SA. 1999. Distribution of mackerel in the Norwegian Sea during Summer, 1991-1998. ICES C 1999/ACFM6/WD

Ibaibarriaga L, Irigoien X, Santos M, Motos L, Fives JM, Franco C, De Lanzós AL, Acevedo S, Bernal M, Bez N, Eltink G, FARINHA A, Hammer C, Iversen SA, Milligan SP, Reid DG. 2007. Egg and larval distributions of seven sh species in north-east Atlantic waters. Fish Res 16: 284-293. DOI: 10.1111/j.1365-2419.2006.00430.x

Jansen T, Gislason H. 2013. Population structure of atlantic mackerel (Scomber scombrus). PLoS One 8 (5): e64744. DOI: 10.1371/journal.pone.0064744
Kloppmann M, Mohn C, Bartsch J. 2001. The distribution of blue whiting eggs and larvae on Porcupine Bank in relation to hydrography and currents. Fish Res 50: 89-109. DOI: 10.1016/S0165-7836(00)00244-7

McGowen GE. 1993. Coastal ichthyoplankton assemblages, with emphasis on the Southern California Bight. Bull Mar Sci 53: 692-722

McKinnon AD, Duggan S, Holliday D, Brinkman R. 2015. Plankton community structure and connectivity in the Kimberley-Browse region of NW Australia. Estuar Coast Shelf Sci 153: 156-167. DOI: 10.1016/j.ecss.2014.11.006

Miesner AK, Payne MR. 2018. Oceanographic variability shapes the spawning distribution of blue whiting (Micromesistius poutassou). Fish Oceanogr 27: 623-638. DOI: 10.1111/fog.12382

Monstad T. 1990. Distribution and growth of blue whiting in the NorthEast Atlantic 1980-1988. PINRO-IMR Symp

Muhling BA, Beckley LE, Koslow JA, Pearce AF. 2008. Larval fish assemblages and water mass structure off the oligotrophic southwestern Australian coast. Fish Oceanogr 17: 16-31. DOI: 10.1111/j.1365-2419.2007.00452.x

Oliver M, Fortuno J. 1991. Guide to ichthyoplankton of the Southeast Atlantic (Benguela current region). Scientia Marina 55 (1): 1-383.

Paulic JE, Papst MH. 2013. Larval and early juvenile fish distribution and assemblage structure in the Canadian Beaufort Sea during JulyAugust, 2005. J Mar Syst 127: 46-54. DOI: 10.1016/j.jmarsys.2012.03.006

Re P, Meneses I. 2009. Early Stages of Marine Fishes Occuring in The Iberian Peninsula. IPIMAR/IMAR, Portugal.

Reid DG, Turrell WR, Walsh M, Corten A. 1997. Cross-shelf processes north of Scotland in relation to the southerly migration of Western mackerel. ICES J Mar Sci 54: 168-178. DOI: 10.1006/jmsc. 1996.0202

Russel F. 1976. The Eggs and Planktonic Stages of British Marine Fishes. London Academic Press, London.

Smith PE, Richardson, Sally L. 1977. Standard Techniques for Pelagic Fish Egg and Larva Surveys. FAO, Rome.

Uriarte A, Luciob P. 2001. Migration of adult mackerel along the Atlantic European shelf edge from a tagging experiment in the south of the Bay of Biscay in 1994. Fish Res 50: 129-139. DOI: 10.1016/S01657836(00)00246-0

Walsh M, Reid DG, Turrell WR. 1995. Understanding mackerel migration off Scotland: Tracking with echosounders and commercial data, and including environmental correlates and behaviour. ICES J Mar Sci 52: 925-939. DOI: $10.1006 /$ jmsc. 1995.0089 